\title{
(De)valuing Intern Labour: Journalism Internship Pay Rates and Collective Representation in Canada
}

\author{
Errol Salamon
}

\author{
McGill University, Montreal, Canada, errol.salamon@mail.mcgill.ca
}

\begin{abstract}
Unpaid journalism internships have attracted increasing media coverage, but they have received limited scholarly attention. This paper traces the connections between trade unions (in unionized media organizations) and the labour conditions marking journalism internships. While some unions can be complicit in sustaining the exploitation and devaluation of interns with regard to the standard market value of entry-level labour, other unions have fought to establish internships, locking higher salaries into collective agreements. Building on the concept of precarity, this article surveys internships at 19 mainstream English-language newspapers and magazines in Canada. It draws on documentary evidence from and personal communication with labour unions and journalism organizations, internship advertisements, and media coverage to offer a typology of the relationships between pay rates and collective representation within journalism internships: unpaid/low paid and not under union jurisdiction; unpaid/low paid and under union jurisdiction; paid at intern rates and not under union jurisdiction; paid at intern rates and under union jurisdiction; and paid at entry-level employee rates and under union jurisdiction.
\end{abstract}

Keywords: low-paid internships, interns, journalism labour, unions, exploitation, precarity, newspaper crisis, political economy, Canada

Acknowledgement: Special thanks to the reviewers and guest editors for their helpful comments. Also thank you to Beth Knobel for comments on an earlier version of this paper, which was presented at the 2015 International Communication Association Conference.

In Canada, unpaid journalism internships received a surge of media coverage in early 2014 after the popular Canadian magazines Chatelaine, Flare, and Toronto Life ceased their internship programs. These programs ended in the midst of the Government of Ontario's clampdown on unpaid internships that contravened the province's Employment Standards Act (Houpt 2014; McKnight 2014). Journalism organizations have used the term "internship" to refer to a variety of work placements typically ranging in length from a period of one week to one year. As in other sectors, most journalism students enrolled in university degreegranting programs are required to do an internship as part of their training and in order to graduate (Internship 2014; Thornton 2011). Many journalism internships or professional fulltime field placements are unremunerated, but students can obtain course credits for doing them as part of their university education. In many Canadian provinces, including Alberta, British Columbia, Manitoba, and Ontario, interns must be paid at least minimum wage unless internship programs provide training for particular professions or training as part of a postsecondary educational program or work experience program (Employment Standards Code, RSA 2000; Employment Standards Act, RSBC 1990; Employment Standards Code, CCSM 1998; Employment Standards Act, SO 2000). Yet many journalism organizations have used the challenges facing the print media industries to justify a growing reliance on unpaid journalism internships (Perlin 2012).

Canadian print media industries (newspapers and magazines) have experienced declining revenues and circulation as the longstanding advertiser-supported and subscription-based business model has waned dramatically (CMCRP 2014; Edge 2014; Winseck 2010). The strategies of print media publishers to sustain profitability and regain audiences have been varied since the 2008 global recession and as digital platforms have continued to spread. For example, between 2009 and 2012, the Postmedia chain reduced the publishing schedules of 
some of its daily newspapers to six days, among them the National Post, the Calgary Herald, the Edmonton Journal, and the Ottawa Citizen (CBC News 2012). Publishers have also transitioned rapidly from print to digital platforms. Since the Victoria Times-Colonist introduced a paywall in 2011, other print publications in Canada followed suit, requiring readers to pay to access content online (CMCRP 2014). ${ }^{1}$ In 2014 Canada had 91 paid daily newspapers, 38 of which had paywalls or metered access, accounting for more than half of the country's daily newspaper circulation (Newspapers Canada 2015,10$){ }^{2}$ In this new digital-first world, print media outlets are publishing on multiple platforms - mobile, tablet, and the weband competing with broadcasters and other digital operations. Additionally, publishers have closed print media outlets, including eight local Quebecor publications in 2013 and one Glacier Media newspaper in 2014 (Dobby and Canadian Press 2013; Lee 2014). Some companies have also laid off employees: for instance, between 2012 and 2014 Sun newspapers eliminated more than 1,000 jobs, and Torstar's Toronto Star reduced its workforce by nine percent (CMCRP 2014; CMG 2013). In addition to instituting paywalls, closures and layoffs, consolidation has marked the strategies of print media publishers. In October 2014, Postmedia purchased Quebecor Media's Sun Media chain for $\$ 316$ million, heightening concerns about newspaper monopolies in Calgary, Edmonton, and Ottawa, and increasing ownership concentration in the country more broadly (Edge 2014).

Turbulence in the print media industries is nothing new. Market instability affected print publishers after a mild recession took hold in the early 1990s, following the onset of the digital transition in the mid-1990s, and after the media were re-regulated in 1996, paving the way for two waves of media consolidation in Canada, 1995-2000 and 2003-2007 (Edge 2014; Skinner, Compton and Gasher 2005; Winseck 2010; Winseck 2011). Amid this upheaval in the sector, two additional facts stand out. First, between 1995 and 2013, most print media companies in Canada have maintained enviable profits. Second, preceding and paralleling these transformations, a wide variety of journalism internships have suddenly emerged and have seemingly become necessary, some of which have been low-paid or unpaid. This paper explores the emergence of journalism internships and offers a typology of the pay relationships and collective bargaining agreements (or lack thereof) that can be used to better understand these work placements.

Journalism internships can be situated within a longer history of struggles that junior and entry-level workers have faced in the print media industries. In the $19^{\text {th }}$ and $20^{\text {th }}$ centuries, young apprentice printers and adolescent newspaper carriers also struggled with their employers over low wages and organized labour unions to negotiate better working conditions and higher pay (Bekken 1995, 2009; Zerker 1975, 42; Zerker 1982, 24-25). In the early 1830 s, printers in particular were at the forefront of the burgeoning labour movement in Canada. Employers were increasingly hiring "halfway journeymen" (printers who had not completed their apprenticeships) and paying them less than the customary wage. This use of cheap apprentice labour was one of the major issues that motivated printers to form the Toronto Typographical Union in 1832, one of Canada's first print media unions.

Although the phenomenon of unpaid and underpaid internships has increasingly been exposed to the international and national media spotlight (e.g., Davis 2013; de Peuter, Cohen and Brophy 2012; Internship 2014; Tatelman 2015), and has been the subject of legal scrutiny (e.g., Doorey 2013; Langille 2014; LCO 2012; Stewart and Owens 2013), more scholarly research is needed. ${ }^{3}$ Media, legal, and scholarly accounts have highlighted the roles of journalism employers, postsecondary journalism programs, government labour legislation, and interns themselves in sustaining an exploitative internship system within an economy increasingly marked by precarious-flexible and insecure-forms of employment. How-

\footnotetext{
${ }^{1}$ In 2004, the Whitehorse Star in the Yukon Territory became the first newspaper in Canada to implement a paywall and still maintains one (Newspaper Canada 2015, 10).

2 By mid-2015, some paywalls had been cancelled. Notably, the Toronto Star (2015) ended its "Digital Access" program, effective April 1, 2015.

${ }^{3}$ Brief scholarly discussions of internships include Bakker (2014), de Peuter (2014a), Gollmitzer (2014), Hesmondhalgh (2010), Madison (2014), McKercher (2014), and Thornton (2011).
} 
ever, these dynamics alone do not offer a complete understanding of the phenomenon without considering the role of labour unions in the internship system.

Building on these media, legal, and scholarly insights, this paper argues that for-profit journalism organizations exploit and devalue the labour of editorial interns ${ }^{4}$ with regard to the standard market value of entry-level labour. By comparing internships that are under union jurisdiction and internships that are not under union jurisdiction, this article also foregrounds the ambivalent role of labour unions, one that illustrates a contradictory tension. In the case of unpaid and low-paid interns that are under union jurisdiction, labour unions have enshrined exploitative and underpaid internships by writing them into collective agreements. Nevertheless, various union locals have fought to establish paid internship programs and collective agreements that have also guaranteed interns entry-level salaries. Within the struggling (but profitable) print media industries, journalism unions must balance conflicting dynamics regarding internships, including union members' professional commitment to the institution of journalism, members' and media corporations' economic interests, and labour movement strategies to protect a growing and a more diverse membership that includes new job classifications-among them interns who may have a desire to work in a creative field such as journalism, regardless of the pay.

To ground this argument, I survey the pay rates and collective representation of interns at 19 mainstream English-language magazines and newspapers in Canada, measuring them against corporate revenues and profits. This paper relies on documentary evidence from, and personal communication with 11 representatives of, labour unions and journalism organizations, internship advertisements, and media coverage of internships. This sample of organizations was selected because of their proximity to many of the country's university-level journalism programs, most of which are based in large urban population centres with 100,000 or more people. ${ }^{5}$ As a point of critique and advocacy, this article builds on the concept of precarity to address internships as not only a "(quasi-) employment status" (de Peuter 2014a, 267) and as work that is unpaid or low-paid (de Peuter 2014b, 32) but also as work that is well paid. The paper examines the specific dimensions of journalism internships to highlight key contradictions within a single industry. As such, it contributes the only comprehensive scholarly study published to date on the varied relationships existing between journalism internship pay rates and collective representation in Canada. Scholars, practitioners, and activists outside of journalism and beyond Canada could learn from this case study, as precarious work and internships are cross-disciplinary, cross-sectoral, and international phenomena. In what follows, this paper discusses these phenomena and examines five contradictory relations between journalism intern pay rates and collective representation: unpaid/low paid and not under union jurisdiction; unpaid/low paid and under union jurisdiction; paid at special intern training rates and not under union jurisdiction; paid at special intern training rates and under union jurisdiction; and paid at entry-level employee rates and under union jurisdiction.

\section{Precarity, Exploitation, Journalism Labour, and Unions}

Precarity and exploitation are concepts that describe historical transformations of work and labour conditions under post-Fordist capitalism. In contrast to the labour relations that prevailed under Fordism, labour precarity is a condition that has expanded since the 1970s (Brophy and de Peuter 2007; Hardt and Negri 2009; Huws 2014). The concept refers to "all forms of insecure, contingent, flexible work-from illegalized, casualized and temporary employment, to homeworking, piecework and freelancing" (Gill and Pratt 2008, 3). Precarity also refers to the "massive reduction of permanent employment contracts...sometimes calling for a high degree of mobility, with or without minimal social security benefits, such as health insurance, paid holidays, or pensions" (Lorey 2010). Another key characteristic of precarity is "earning low income" (LCO 2012, 11, 27). To articulate a social subject united across a range

\footnotetext{
${ }^{4}$ Editorial internships typically fall under the following job classifications: reporter, copy editor, and photographer.

${ }^{5}$ Given the difficulties in obtaining this kind of information, some major journalism organizations are not sampled in this paper due to a lack of available data.
} 
of diverse employment conditions, Guy Standing $(2011,1)$ describes the "precariat," a global political subject "without an anchor of stability." Linking "precarious" with "proletariat" (7), this neologism names a subject that-unlike the Marxian proletariat-is defined by intermittent participation in the labour force. The precariat must accept a range of unpaid employment relationships, ones that are increasingly necessary to maintain access to permanent jobs and a living wage.

Precarity, along with marketization, government deregulation, privatization, and digitalization, has also weakened the collective bargaining power of trade unions, including in cultural industries such as journalism (Hesmondhalgh and Baker 2011). Unions have typically organized for stable, predictable employment, a living wage, and benefits, but they have struggled to organize workforces made flexible and temporary, with workers who tend to have short-term employment relationships with their employers and unions (Huws 2014; Ursell 2000). Overall union membership as a percentage of the workforce has declined steadily. Between 1981 and 2012 Canada's unionization rate decreased from 38 percent to 30 percent, even though it has remained relatively stable since 1999 (Galarneau and Sohn 2013, 1). At the same time, "alt-labour" groups such as the Canadian Intern Association have emerged to organize among the precariat by using direct action, legal action, and other tactics (Cohen and de Peuter 2013). Alt-labour groups are among the alternative social movement organizational forms that have emerged alongside trade unions to help renew, diversi$\mathrm{fy}$, and raise equity issues within the established labour movement (Fletcher, Jr. and Gapasin 2008; Foley and Baker 2009; Kumar and Schenk 2006; Milkman and Ott 2014; Mosco and McKercher 2008). Labour unions bargain collectively, which could guarantee precarious workers ongoing labour protection. Regardless of unions' decline, then, it is difficult to argue with the sentiment that unions still serve as "the worker's best defence" in an increasingly unpredictable labour market (Head 2003, 172).

Underpaid and unpaid internships are one of a constellation of these precarious employment relationships (LCO 2012, 11, 27). Internships are precarious in a number of respects, most significantly because they are temporary positions by definition and rarely come with the labour force protections or social security benefits enjoyed by permanent and full-time workers. These conditions are especially pronounced among Canadian youth aged 15 to 24 , who in 2012 had a considerably higher unemployment rate-14.3 percent-compared to the national average of 7.2 percent (Galarneau, Morissette and Usalcas 2013, 1). The challenges faced by youth to break into the workforce have led many of them to accept underpaid internships, and young people are now increasingly expected to undertake these placements before entering the paid labour force (Huws 2014; LCO 2012).

Precarious labour is evident in the print media industries (Deuze 2007, 20-27). At for-profit journalism organizations, due to factors such as technological change, decreased revenues, and constrained organizational budgets, the processes contributing to precarious employment of white-collar editorial workers include offshoring, outsourcing, mass layoffs, and slower pay increases (Cohen 2012; Deuze and Marjoribanks 2009; Örnebring 2010; Paulussen 2012). For example, from 2001 to 2011, journalists' median incomes increased proportionally less than the overall median income in Canada and did not keep up with inflation (Skelton 2013). While journalism organizations have remained profitable, they have exploited the labour of journalists by making them work for less than the standard market value that is generated from their labour.

A focus on editorial workers, who typically identify as professionals, can illuminate the exploitative social relations within the organizational division of labour in journalism production (Hesmondhalgh and Baker 2011, 67) and the "hierarchical division of newsroom labour" (Solomon 1995, 111). ${ }^{6}$ Editorial workers elucidate what William S. Solomon calls a "middleclass ideology of newswork" and what Erik Olin Wright $(1997,19)$ refers to generally as "the problem of the 'middle class' among employees": workers who do not own the means of pro-

\footnotetext{
${ }^{6}$ Workers can be placed on different levels of the hierarchy, for instance, middle-level managers, higher-skilled editors, reporters, and photographers, and non-skilled workers who do routine jobs, such as delivery drivers and mail sorters.
} 
duction and sell their labour, but do not identify as members of the working class, tend to be well educated, and have privileged positions relative to other occupations. Nevertheless, editorial workers are still exploited because they do not occupy powerful positions within the broader social division of labour (Hesmondhalgh and Baker 2011,69).

Journalism internships are one of a constellation of these precarious and exploited employment relationships. In order to provide more nuance to the organizational division of labour in the print media sector, this paper includes an analysis of internships by way of offering what is referred to as a job classification division of labour within editorial work. This notion highlights the fact that although the journalistic labour of all editorial workers may be exploited, underpaid and unpaid intern labour is more exploited relative to that of other editorial employees. Part of the reason for the greater levels of exploitation is the growing "reservoir of labour" of junior workers competing for paid positions, resulting in a surplus of labour in the print media industries (Hesmondhalgh and Baker 2011, 114). This surplus can be attributed to several factors, including job cuts and an increase in the number of university graduates. It is in this context that journalism internships have multiplied, many of which are unremunerated or low paid. Competition for internships, especially of the paid variety, is stiff. By 1997 in the United States only 57 percent of journalism students reported that they could get a paid internship. Since 2010, only 34 percent of students could find a paid placement (Internship 2014). ${ }^{7}$

Although today's internships may offer only minimal legal protections, some young workers still accept these placements, hoping that unpaid and low-paid positions lead to wellremunerated and stable employment (de Peuter 2014a; Perlin 2012; Ursell 2000; Ursell 2003). Aspiring journalism workers sometimes feel obligated to accept this partial participation in labour, as they "self-exploit" and "gift" their free labour to secure access to continuous employment and a living wage (Ursell 2000, 814, 821). Workers also willingly accept these positions because of the hype that has been generated about the "desirability of creative labour" in the media industries (Hesmondhalgh 2010, 279). To offer low-paid or unpaid internships is ultimately to lower the market value of entry-level labour, that is, to pressure labour to work for less (Gould 1981, 147).

One way that editorial workers-including interns-can resist the devaluation of their labour is through collective organization. Since 1891, print media labour unions have fought for higher wages and better working conditions for editorial workers. At that time, a wage disparity between unorganized editorial workers and the organized newspaper workers in mechanical departments became an issue around which the former initially mobilized in Pittsburgh, Denver, Sacramento, and New York (Bernstein [1969] 2010, 127; Solomon 1995, 127-128). Editorial workers also organized because newspaper work was insecure: editors and publishers would fire employees at will, and a plethora of newspaper mergers in the early 1930 s led to massive job cuts (Bernstein [1969] 2010, 127-128). As these workers lacked job security and labour protections, it is clear that precarity is not only a contemporary condition.

Until 1891, editorial employees had remained nonunionized because they typically viewed themselves as "intellectuals of the fourth estate" (Lord 1950, 25) whose professional journalistic standards were irreconcilable with collective organizing in trade unions. The professional identity of editorial workers was characterized by individualism, competitiveness, and a belief that they had a commitment to the craft of journalism rather than to the interests of other workers. As newspaper work became more specialized at the turn of the $20^{\text {th }}$ century, university-level journalism programs emerged as a training ground for aspiring journalism professionals (Salcetti 1995, 60-65). However, this commitment to journalistic professionalism could "obscure relations of exploitation" among other journalism workers (Cohen 2011, 123), as editorial workers were expected to pay their dues before earning higher wages. The idea

\footnotetext{
${ }^{7}$ Paid internships have a longer history. For instance, the Dow Jones Newspaper Fund established a paid reporting internship program in 1960 to bolster the quality of journalism education and the pool of job applicants in the United States (DJNF 2015). That year the Fund supported 53 university students with summer internships at 45 newspapers. In 1964108 interns received \$500 at the completion of their 10-week placements (Logan 1965, 624).
} 
that journalism workers should pay their dues has shaped unions' approaches toward internships.

It was a growing awareness of these precarious conditions that led the International Typographical Union (ITU) to organize 59 newswriters' locals in more than 40 cities across the United States and Canada between 1891 and 1923 (Leab 1970, 13). Most of them lasted for fewer than five years, however. In 1923, the ITU relinquished jurisdiction of newswriters to the American Federation of Labor (AFL), with the exception that the two remaining ITU newswriter locals in Milwaukee and Scranton could stay in the international union (Bernstein [1969] 2010, 127). The AFL chartered newswriters locals in seven cities, including Montreal, between 1923 and 1930, but by 1933, only the Boston and Chicago locals had survived. In September 1936, the American Newspaper Guild (ANG) began to organize editorial newsworkers in Canada, three years after the Guild was founded in the United States (Unifor87-M 2013). A small group of editorial workers at Toronto newspapers aimed to unionize the city's four daily papers, and the Toronto Newspaper Guild (TNG), Local 87 of the ANG, was born. This drive to unionize journalists and other cultural industries workers was precipitated by the Great Depression and a broader industrialization of culture (Denning 2010; Lord 1950).

Since the 1940s, editorial newspaper workers have organized around the country, as labour legislation established provisions on union certification and compulsory collective bargaining. Although labour relations fell under provincial jurisdiction in Canada, the federal government established the Wartime Labour Relations Regulations, 1944 to oversee labour relations across the country during World War II. In 1947, the federal government introduced amendments to the Regulations to return jurisdiction to the provinces, but provincial governments enacted similar legislation, for instance, British Columbia's Industrial Conciliation and Arbitration Act, $1947^{8}$ and Ontario's Labour Relations Act, 1948 (Dorsey 1977, 391; Fudge and Tucker 2001; OLRB 2013). ${ }^{9}$ These legislations enabled labour relations boards to certify unions as the official bargaining agents for employees.

Despite this long history of unionizing editorial workers, some of the Ontario-based newspapers and magazines examined below have been organized only since the early 1980s. In the 1960s and 1970s the TNG developed a "cosy" working relationship with print media companies and did not see organizing new groups of employees as a priority (Unifor87-M 2013). Still, in the late 1970s TNG changed its name to the Southern Ontario Newspaper Guild (SONG), acknowledging that it represented members outside of Toronto, too. In the early 1980s, union members elected new officers with a mandate to organize more newsrooms, and unionization drives took off, leading to a long period of expansion that extended into the early 2000s. The dual aims of the earlier organizing attempts still mark the journalistic culture to which members of editorial unions subscribe: attaining and maintaining professional standards and higher wages.

In a precarious media labour market characterized by weakened labour union protection and employment legislation, and declining union membership, media unions have merged and consolidated collective bargaining negotiations to strengthen their power (Hesmondhalgh and Baker 2011; McKercher 2002; Mosco and McKercher 2008). Unions such as Unifor and the Communications Workers of America-Canada (CWA-Canada) now represent media workers across the print, telecommunications, broadcasting, and online industries, among others. Their print media members come from both editorial and mechanical departments across Canada and the United States. For example, the CWA initiated labour "convergence" as a gradual strategy around 1980 and this process intensified after 1991, when the union proclaimed that its goal was to organize entire workplaces rather than only groups of workers (Mosco and McKercher 2008, 115). By the 1980s, corporate concentration of media corporations had accelerated, with government re-regulation facilitating further cross-media corporate expansion (McKercher 2002, 186). A major outcome of labour convergence was that Local 87 left The Newspaper Guild (formerly known as the American

\footnotetext{
${ }^{8}$ The Act was amended in 1948 to create the Labour Relations Board.

9 Ontario's Collective Bargaining Act, 1943 was among the first attempts to establish compulsory collective bargaining in Canada.
} 
Newspaper Guild) in 1994 and affiliated with the Communication, Energy, and Paperworkers Union (CEP), the biggest union of print media workers in the country, which had 15,000 members in its media section (Unifor87-M 2013). The Newspaper Guild also granted its Canadian members more autonomy in 1995, founding TNG Canada, around the same time that it merged with the CWA; in 2007, TNG Canada became CWA Canada (CWA Canada 2015). In 2013, the CEP merged with the Canadian Auto Workers Union, forming Unifor to deal with declining union membership following the 2008 global recession (Unifor87-M 2013).

Thus, journalism unions have struggled to balance a series of strategic objectives, including a commitment to professional growth, a fight for higher wages in industries that have experienced declining revenues and profits, and the development of strategies to protect an expanded and more diverse group of workers that includes new job classifications. Among this diverse group are interns, who, as we have seen, still manifest a desire to work in creative industries despite the precarious working conditions marking them.

\section{Journalism Internships in Canada}

Table 1 summarizes the varied set of relationships that exist between journalism internship pay rates and collective representation at the publications I surveyed. The table includes the most recent information on annual revenues, earnings, and profit margins of the publications' owners, ${ }^{10}$ as well as the number of interns working at these magazines and newspapers at any one time.

First, many internships are unpaid or low paid and not under union jurisdiction. Unpaid magazine internships in Canada emerged after a mild recession in the early 1990s, when some magazine owners experienced a slight decline in revenues (Jay 1995; Winseck 2010; Winseck 2011). One example is Flare's internship program, which has been unpaid since it was introduced in 1991. Although this program was temporarily shut down in 2014, the Rogers Communications-owned fashion magazine has begun to offer unpaid internships to students who can receive university course credits for their placements (Flare 2014; Jay 1995; McKnight 2014; Tant 2010; Alicia Cox Thomson, pers. comm.). Flare generally hires about six interns at a time, three times per year, each of whom work full-time for four months in one of the following departments: fashion, beauty, entertainment, design, research, or Flare.com. Chatelaine, a Rogers-owned women's magazine that also recently ceased its internship program, compensated interns only $\$ 400$ monthly. The magazine began an experimental internship program in 1994-1995 by hiring interns from community colleges (Jay 1995). Before cancelling its program in 2014, Chatelaine hired web, editorial, and copy/research interns to work between three and five days per week over four or six months (Baluja 2013). In 2013, while interns earned little to nothing, Rogers Media, which includes the company's media assets, generated $\$ 1.7$ billion in operating revenue and $\$ 160$ million in adjusted operating profit, with a profit margin of 9.4 percent (Rogers Communications 2014, 1, 47). ${ }^{11}$

Like Chatelaine, Toronto Life also paid its interns a stipend from the time it started its internship program in 1993 until after the global financial crisis unfolded in 2009, when internships became unpaid placements (Houpt 2014; Jay 1995). Editorial interns (general, fashion and lifestyle, and food and drink) were expected to work full-time for four months, except online interns, who could work part-time for at least three days per week (Toronto Life 2014). In 2014 the magazine ended its internship program after 21 years, dismissing five interns (Houpt 2014). Soon after, Toronto Life (2015) reopened its unpaid internship program to students enrolled in academic programs who require intern experience to graduate. Despite a lack of remuneration for interns, the magazine is owned by St. Joseph Communications, a company that generated $\$ 32.3$ million in revenue in 2013 , an increase from $\$ 28.5$ million in 2008 and $\$ 29.8$ million in 2010 (CMCRP 2013). ${ }^{12}$

\footnotetext{
${ }^{10}$ Based on 2013 data from publicly traded companies, as available.

${ }^{11}$ Rogers Media includes television, radio, digital media, sports entertainment, and magazine publishing, the latter of which generated 14 percent of the total Media operating revenue. Information about publishing profit was unavailable.

12 Earnings and profit margin data for St. Joseph Communications were unavailable.
} 
ELLE Canada (2011) pays its editorial-beauty and editorial-web interns, but only $\$ 750$ at the end of a four-month placement. Interns are expected to work seven hours per day over three to four days per week. The magazine tends to hire recent graduates and students with journalism experience. The publication is owned by TC Transcontinental, whose assets from TC Media (its newspaper and magazine division) generated $\$ 712$ million in revenue and $\$ 40$ million in adjusted operating profit in 2013 (TC Transcontinental 2013, 13). Although these companies are profitable, they pay all of their interns significantly below the $\$ 11.25$-per-hour student minimum wage in Ontario, where the magazines are based.

Second, interns at some organizations are unpaid or low paid and under union jurisdiction. Since Toronto Sun workers organized with SONG, a local of Unifor, in 2003, its collective agreement has stipulated that it may hire up to four unpaid journalism student interns at a given time including a photo intern (CEP 2008a, 18; CEP 2011d, 18-19; Unifor87-M 2013). By contrast, the paper's multimedia journalists earn $\$ 51,538$ yearly, and columnists make $\$ 77,216$ annually (CEP 2011d, 72, 78). ${ }^{13}$ Similarly, since Ottawa Sun workers first organized with SONG in 2006, its collective agreement has allowed up to three journalism student interns to work unremunerated in the paper's newsroom for a maximum of eight weeks (CEP 2007c, 6; CEP 2011c, 18; Unifor87-M 2013). Compared to this free intern labour, multimedia content providers are paid $\$ 707$ weekly, and columnists earn $\$ 1,033$ per week (CEP 2011c, 54-55). Likewise, according to SONG's collective agreement with the London Free Press, which has been organized since 1989 , the paper has also been able to hire unpaid interns since at least 2007 (CEP 2007a; Unifor87-M 2013). In 2013 the newspaper could hire up to four unremunerated student interns per year but only one intern at any given time to work for a maximum of one month (CEP 2007a, 42; CEP 2013b, 44). This free intern labour is in stark contrast to the profit of the papers' owners. The Sun and Free Press newspapers are owned by Sun Media Corporation, a subsidiary of Quebecor Media, whose news media operations generated $\$ 784.2$ million in revenue and $\$ 97.7$ million in adjusted operating profit in 2013, with a profit margin of 12.5 percent (Quebecor Media 2014, 37).

Other unionized publications run low-paid internships. Since at least 2009, the Rogersowned Maclean's $(2009 ; 2014)$ has offered a full-time program that pays $\$ 22,500$ annually and a full-time three-month summer program paying $\$ 1,750$ monthly, both of which are open to anyone interested in journalism. When hiring summer interns, the magazine tends to prioritize students entering their final year of study. The magazine's editorial workers have been represented by SONG since 1983 (Unifor87-M 2013). In the 1990s, when competing magazines Flare, Chatelaine, and Toronto Life started internship programs, SONG prevented the use of interns and unpaid work at Maclean's. After 2003, the Guild incorporated a paid internship program into the magazine's collective agreement (CEP 2001; CEP 2007b; Jay 1995). Although Maclean's currently remunerates its interns, the salaries may seem surprising considering it classifies yearlong interns as "full-time entry-level journalists" (Maclean's 2014). According to its collective agreement, though, Maclean's is obligated to provide students with only an "honorarium of not less than $\$ 1,000$ for a four month period or $\$ 250$ per month or part thereof" (CEP 2007b, 10; CEP 2011b, 26-27). By contrast, Maclean's pays its full-time entry-level staff significantly higher yearly starting rates: $\$ 35,000$ for reporters and $\$ 48,000$ for researchers/reporters (CEP 2011b, 59-62). The agreement has limited the magazine to only two internship placements at any given time, and up to two placements annually in each department, except for the research department, which may offer one student placement and two Ann MacGregor Memorial Internships yearly.

Third, some interns are paid at intern rates and not under union jurisdiction. Canadian Business hires two early-career journalist interns full-time for 12-month periods each year, remunerating them $\$ 2,000$ monthly (Canadian Business 2014; Graham F. Scott, pers. comm.). The program was founded in 1995, becoming "the first paid magazine internship in Canada" and "one of the country's highest paid internship positions" (quoted in Baluja 2014). The company has even increased its intern salary with inflation: from 1998 to 2004, for example, it paid $\$ 1,500$ monthly (Renzetti 1998; Scratch 2004). However, Canadian Business

\footnotetext{
${ }^{13}$ In 2015, the Toronto Sun sought multimedia journalists for "paid" summer internships (Gaulin 2015).
} 
and Maclean's are based in Toronto-one of Canada's most expensive cities for housingand these salaries are insufficient to financially support interns. These earnings hover around the low-income cut-off of $\$ 23,647$ before taxes for one person in metropolitan areas of 500,000 or more inhabitants, such as Toronto (Statistics Canada 2013).

Like the Canadian Business internships, the Calgary Herald's summer program is neither unpaid, nor low-paid, nor under union jurisdiction. The paper's internship program has existed since at least 1985 (Lorne Motley, pers. comm.). The Herald hires three or four students or recent graduates during the summer, paying them around $\$ 20$ per hour to work full-time for four months. This pay rate has outpaced inflation-in 2000 the Herald paid its interns $\$ 14$ per hour (Motley, pers. comm.). To determine the appropriate rate, the "HR department conducts regular reviews of competitive starting and internship salaries in the marketplace" (Motley, pers. comm.). Nevertheless, the Herald is part of the Postmedia conglomerate, which generated $\$ 751.6$ million in revenue and $\$ 130.4$ million in earnings in 2013 , with a profit margin of 17.3 percent (Postmedia 2013, 9, 21). Although Canadian Business (a Rogersowned publication) and the Herald may pay a competitive wage, they also leave interns with little power to bargain collectively for higher wages. In 2000 the Herald even resisted CEP Local 115A's fight to get a first contract for the newsroom during a legal strike by hiring replacement workers, among them a Carleton University summer intern (CEP 2000). The strike led the union local to decertify.

Fourth, interns at some publications are paid at intern rates and under union jurisdiction. The Victoria-Vancouver Island Newspaper Guild (VVING), Local 30223 of the CWA-Canada, represents Victoria Times-Colonist interns. When VVING first established the newspaper's paid editorial internship program in 2002 , it negotiated a weekly intern salary of $\$ 530$, and in 2006 , the rate increased to $\$ 554$ weekly, permitting the paper to hire up to four interns yearly (Chris Carolan, pers. comm.; VVING 2011, 133). The program is open to students, and interns are hired to work full-time for up to a maximum of 20 weeks between May and September. However, the intern pay rate has not increased since 2006, even though other editorial employees have received pay raises: for example, in 2013, first-year reporters and photographers earned $\$ 1,033$ weekly, more than double the intern rate (VVING 2011, 39). Despite this salary difference, the Times-Colonist has not hired interns every year (Carolan, pers. comm.). Nevertheless, the newspaper is owned by Glacier Media, a company that in 2013 generated \$295.6 million in revenue and \$32.7 million in earnings, with a profit margin of 11.1 percent (Glacier Media 2013, 14).

Another company in this category, the SONG-unionized Toronto Star, hires 30 to 32 interns annually across its four internship programs, with varying special intern training pay scales (CEP 2013c, 70; Peter Cooney, pers. comm.; Toronto Star 2014). The summer reporting internship is a full-time position that ranges from 10 to 14 weeks. The one-year reporting internship is also a full-time placement and is only open to recent graduates. The fall and winter radio room internships are part-time placements that are open to students, whereas the summer radio internships are full-time positions for students. In 2013 Star editorial interns earned $\$ 954$ weekly, and this salary has increased with inflation from about $\$ 700$ in 1999 (CEP 2013c, 158, 172; Stone 1999). In 2013 the paper's first-year journalists earned only marginally more-\$1,046-up from around $\$ 700$ in 1999 (CEP 2013c, 154; Stone 1999). Nevertheless, radio room interns earned $\$ 17$ per hour in 2013 (CEP 2013c, 94).

SONG did not passively lock these interns into a lower-paid contract, though. In the late 1990s the local fought to create the radio room internship program in order to integrate younger voices into the newsroom. Its aim was to "staff [the radio room] with cheaper students," providing the students with part-time newsroom experience and enabling experienced journalists to work on the "bigger news" (Laidlaw 2013). Like VVING, the Guild also established a "special editorial trainee wage category and pay rate" in collective bargaining. Simultaneously, SONG launched its bigger "editorial intern program," which provides 12 one-year reporting internships. The radio room is generally staffed with 12 interns during any particular contract period (Ladurantaye 2013). In 2013 the Guild agreed to an hourly pay decrease from $\$ 25$ to $\$ 17$ for radio room students to prevent the Star from terminating that internship program (CEP 2013a; Ladurantaye 2013; Laidlaw 2013). As a result of declining advertising 
revenues, the paper planned to reduce the radio room's $\$ 250,000$ annual cost and outsource the work to Pagemasters, a company that could provide the same services at a discounted rate. In March 2013, Stuart Laidlaw, SONG unit chair of the Star, said that the radio room program has trained many Star reporters, and the pay cut was a way to balance an investment in young journalists' professional training with the paper's economic interests: "[The radio room] is a real incubator-you get to test drive a young reporter at a relatively affordable rate" (quoted in Ladurantaye 2013). Although the Star pays its interns a training rate, the media segment of the Torstar-owned newspaper generated $\$ 984$ million in revenue and $\$ 130.7$ million in earnings in 2013 , with a profit margin of 13.3 percent (Torstar 2013,18).

The Winnipeg Free Press is another unionized newspaper whose internship programs are subject to a special intern training pay class. The paper's summer and school-year internships are open to journalism students or recent graduates. Since at least 2008, Free Press interns have been covered under the collective agreement of Unifor Local 191 (CEP 2008b, 48). The paper's full-time summer reporter interns are "paid in accordance with the collective agreement at 65 percent of the starting wage for a reporter" (CEP 2013d, 59; Steve Pona, pers. comm.). According to this agreement, the starting weekly rate for reporters is $\$ 866$ (CEP 2013d, 56), even though reporter interns "perform all of the functions of a working journalist" (Winnipeg Free Press 2014). Still, the Free Press offers similar six-week (30 working day) school-year internships, paying students a $\$ 50$ weekly honorarium. This program is open to two students at any one time, except in December and January, when the paper may hire up to four interns (CEP 2013d, 59). FP Canadian Newspapers, the publication's owner, generated $\$ 106.3$ million in revenue and $\$ 20$ million in earnings in 2013 , with a profit margin of 18.8 percent (FP Newspapers $2013,20,44$ ). Significantly, most of work placements in this category still demonstrate that it is feasible to pay interns at least minimum wage and the equivalent of the low-income cut-off.

Fifth, at other publications interns are paid at entry-level employee rates and under union jurisdiction. The Globe and Mail is one such publication that pays summer interns the equivalent of the SONG rates for reporters, editors, and digital specialists (Stead 2013). The Globe's full-time summer program was established and well recognized by 1974 . Since then, the paper has offered between 10 and 25 summer positions annually; since the 2000s, it has hired around 18 to 20 summer interns yearly (Sue Andrew, pers. comm.; Sylvia Stead, pers. comm.). These internships are not typical, though, as they are open to students and experienced journalists. They have always been covered under the collective agreement because these interns are considered contract staff. However, this internship or "vacationreplacement" program differs from the paper's school-year work-study program, created in the early 2000s (Andrew, pers. comm.). From 2009 to 2013 the Globe's work-study programs of up to six weeks paid post-secondary students a $\$ 125$ weekly honorarium (Andrew, pers. comm.; CEP 2009, 32, 73). Yet, from 2002 to 2009, up to 10 students per calendar year were permitted to participate in a work-study program and were paid a $\$ 250$ weekly honorarium (CEP 2002a, 3, 22). In 2013, Woodbridge, the holding company for the Thomson family that owns the majority interest in the paper, generated $\$ 272.1$ million in revenue (CMCRP 2013). ${ }^{14}$

Some unionized newspapers pay all of their interns an entry-level salary. One exemplar is the Waterloo Region Record, a newspaper that has been represented by SONG since 1989 (CEP 2011e, 22; Unifor87-M 2013). Torstar subsidiary Metroland Media Group publishes the Region Record, where reporters and photographers were paid $\$ 703$ weekly, and copy editors earned $\$ 1,134$ weekly in 2013 (CEP 2011e, 24). Since at least 1999, this pay class has applied to interns who are hired on full-time placements of at least one month (CEP 2003a, 24). Yet in 2013 the Region Record employed only one rather than two news interns, and hired only three summer interns (compared to four in 2011 and in 2012) to reduce organizational spending (Haddrall 2011; Haddrall 2012; Haddrall 2013; Learn 2013). The paper tends to hire journalism students or recent graduates.

\footnotetext{
${ }^{14}$ Earnings and profit margin data for the Globe were unavailable.
} 
Metroland Media's Guelph Mercury interns also "become members of [SONG's] editorial bargaining unit, subject to all contract provisions" (CEP 2011a, 13). Interns must be journalism school graduates, have postsecondary education in journalism, or possess journalism experience as a student. Mercury editorial workers certified with SONG in 1991 (Unifor87-M 2013), and the internship program was launched in the early 2000s under union jurisdiction (Joanne Shuttleworth, pers. comm.). In May 2003 the Guild ratified a new contract, "tightly" limiting the paper's proposal for editorial interns (CEP 2003b). In 2013 the starting rate for reporters and photographers was about $\$ 564$ weekly, and for copy editors it was around $\$ 876$ weekly (CEP 2011a, 14). The Mercury may hire full-time interns for terms of up to one year, with no more than a single one-year intern at one time, a condition that was written into the collective agreement when the internship program began (CEP 2002b, 16-17; Ray 2009). Sometimes the paper hires a summer intern, too (Shuttleworth, pers. comm.). Due to the global recession, however, the intern program was suspended in 2009 after Torstar laid off employees across its chain, 13 of whom were Guelph Mercury newsroom employees (Canadian Press 2009; Ray 2009; Shuttleworth, pers. comm.). The Mercury transferred editorial positions to the Waterloo Region Record, its sister paper. After 2009, the internship program was revived, but its status varies from year to year. The program is reconsidered annually when the Mercury plans its budget, so it is uncertain if interns will be hired in the following year.

The Postmedia-owned Ottawa Citizen is another newspaper that pays interns the starting rates for copy editors, photographers, and reporters, as outlined in its collective agreement with CWA-Canada Local 30205, the Ottawa Newspaper Guild (ONG). The latter fought to establish an intern "orientation" and "training" program, which the Citizen was obligated to implement by January 1, 2001 (ONG 2013, 43). The collective agreement currently limits the paper to six full-time interns at one time, including one copy editor, one photographer, and four reporters (ONG 2013, 5). In 2013 copy editors earned $\$ 1,143$ weekly, and photographers and reporters earned $\$ 1,024$ weekly (8).

Likewise, Postmedia's Pacific Newspaper Group-owned Vancouver Province and Vancouver Sun have always tied their intern pay rate to the full-time entry-level wage of regular employees (Valerie Casselton, pers. comm.; Gary Engler, pers. comm.). By 1968 the Sun ran what was considered the biggest internship program in Canada for student journalists at the time (Valpy 1968). In 2013 the Province and the Sun could hire up to six interns (reporters, copy editors, and photographers) at one time per newspaper, as outlined in their joint agreement with Unifor Local 2000, the Media Union of B.C. That year reporters and photographers earned $\$ 1,038$ weekly, and copy editors earned $\$ 1,113$ per week (CEP 2007d, 15, 25-27, 29; Mercer 2012). Interns must be graduates of a journalism program. However, the Province hired only four interns in 2012 and in 2013, including for its 3.5-month full-time summer program, but it did not employ any interns in 2014 or 2015 (Engler, pers. comm.; Mercer 2012). Similarly, the Sun hired only three interns in each 2013 and 2014, but it was unable to hire interns in 2015 due to budget constraints (Casselton, pers. comm.; Engler, pers. comm.). By contrast, the paper hired as many as 14 summer interns around three decades ago. When set against unpaid, low-paid, and special intern rate placements, these internships demonstrate that it is possible to pay interns an entry-level salary.

\section{Tensions and Contradictions Within Journalism Internships Under Union Jurisdiction}

I have argued that, just as the printing firms of the 1830s exploited young apprentices (Zerker 1975; Zerker 1982), some of today's for-profit magazines and newspapers exploit and devalue the labour of interns with respect to the standard market value of entry-level labour. Just as editorial work during the late 1800 s and early 1900 s was insecure and employees lacked labour protections (Bernstein [1969] 2010), many of today's journalism internships are exemplars of precarious employment relationships. Yet unlike the earlier print media unions, which became workers' best defence against exploitation, devaluation, and precarity, the case of journalism internship pay rates and collective representation in Canada demonstrates the 
contradictory roles that labour unions play in this system today: while some unions have perpetuated exploitation by locking interns into unpaid, low-paid, and training rate placements, others have actively aimed to ensure that interns have been paid well above minimum wage for their work and been offered training and mentorship.

On the one hand, some unions have locked unpaid, low-paid, and training rate internships-the category with the highest number of placements-into their collective agreements. The pay rates of some internships under union jurisdiction are comparable to placements that are not under union jurisdiction. Like the nonunionized magazines Flare and Toronto Life, unionized newspapers such as the Toronto Sun, Ottawa Sun, and London Free Press have offered unpaid internships. Even the nonunionized magazines Chatelaine and Elle Canada have paid interns at least a stipend. Similarly, the nonunionized publications Canadian Business and Calgary Herald have paid a special intern training wage that is comparable to the intern-training rate of unionized publications such as the Winnipeg Free Press. Although the Herald has paid a competitive wage that has increased with inflation, it used an intern as a replacement worker to help defeat CEP Local 115A after the newsroom union struck to get a first collective agreement. The outcome of this strike contradicts Gregor Gall's $(1997,157)$ claim that union de-recognition in the print media industries leads to "[p]ay rises below the level of inflation" and "lower starting rates" (at least for interns at one publication), but it confirms that interns are contingent, expendable, and precarious workers.

The pay for these internships is low when compared to the salaries of permanent employees whose jobs interns have been sometimes expected to temporarily replace during vacations. Although most of these internships are considered postsecondary "training" and journalism organizations are therefore not legally obliged to remunerate interns, the positions closely resemble paid and stable entry-level jobs. Some of the intern pay rates have varied even within unionized publications, among them placements at the Toronto Star, the Winnipeg Free Press, and the Globe and Mail. Thus, they are indicative of not only an organizational division of labour and a "hierarchical division of newsroom labour," but also what I refer to as a job classification division of labour within editorial work (cf. Hesmondhalgh and Baker 2011, 67; Solomon 1995, 111). While all editorial workers at print media companies may be exploited, the conditions for many if not most interns are relatively more exploitative. Entrylevel journalism workers are part of the precariat and must increasingly accept these unpaid or low-paid internships to secure access to continuous employment and a living wage (Standing 2011).

Media companies have used underpaid internships as well as cuts to stable jobs and the limitation of salary increases to reduce organizational spending. Companies have claimed that the cuts and limits are necessary because their revenues and profits have declined since 1990, especially following the 2008 global recession. Yet many of the internship programs surveyed here emerged after 1990, under the increasingly precarious labour market conditions brought about by post-Fordist capitalism. The rise of unpaid and low-paid internships in the Canadian print media sector, a relatively well-unionized setting historically, seems to confirm Ross Perlin's $(2012,71)$ observation that "union presence seems to have made little difference" in stemming the growth of this emergent form of precarious employment.

On the other hand, unions have also created opportunities for aspiring journalism workers by launching paid editorial internship programs. These union-initiated internships have become part of a strategy to balance competing objectives, such as protecting a larger and more diverse labour force, negotiating economic interests, and committing to professional journalism training. Exemplars surveyed here have included VVING's the Victoria TimesColonist, SONG's the Toronto Star, the Guelph Mercury, and The Globe and Mail, as well as ONG's the Ottawa Citizen. Most of these programs were established in the late 1990s and early 2000s. It is not surprising that certain paid unionized internships emerged after 1990, as journalists at some publications became organized only around that time, such as the Guelph Mercury and the Waterloo Region Record. These internships and organizing drives were arguably an outcome of labour union convergence, illustrating the expanded scope of collective bargaining in the print media industries (McKercher 2002; Mosco and McKercher 2008). 
Yet union-created journalism internships have highlighted tensions within unions, especially following the 2008 recession. Time-Colonist interns have earned the same salary since 2006, even though other editorial employees have received raises. Conversely, the Globe's low-paid work-study honorarium was cut by 50 percent. Likewise, SONG negotiated an intern pay decrease to save the Toronto Star's radio room internships after the paper considered outsourcing the labour, while other editorial workers received pay increases. Despite this pay cut, the $\$ 17$ hourly rate of radio room interns is high compared to most journalism internships that are not under union jurisdiction. These examples demonstrate that media unions have struggled to meet similar objectives since the late $19^{\text {th }}$ century, but they have increasingly established and protected internship programs as a key priority in balancing those objectives.

Union members have also ratified collective agreements that guarantee interns an entrylevel salary. Of the journalism internships surveyed here, it is clear that only internships under union jurisdiction have been remunerated at this rate at The Globe and Mail (summer program), the Waterloo Region Record, the Guelph Mercury, the Ottawa Citizen, the Vancouver Province, and the Vancouver Sun. Many of these internships have paid workers nearly $\$ 1,000$ weekly, and at some newspapers interns have earned more per week. Similarly, editorial interns at the Toronto Star earned a high weekly salary of nearly $\$ 1,000$ at the special intern rate. These placements are evidence that unions are not necessarily complicit in devaluing intern labour.

However, some newspapers have not hired or have reduced the number of interns who are paid an entry-level salary, among them the Guelph Mercury, the Vancouver Sun, and the Vancouver Province. Likewise, the Victoria Times-Colonist has not hired interns who are paid a special training rate. In addition to the job cuts mentioned above, these newspapers have attributed their decisions to declining revenues and profits. The purported necessity of these cuts has been called into question, though, by highlighting the profit margins of journalism organizations: all of the eight ownership groups surveyed in this paper and for which data were available remain profitable, with six maintaining double-digit profit margins. Marc Edge (2014) refers to the disparity between figures such as these and the dire claims coming from industry observers and executives as pointing to the "myth" of the newspaper crisis. My research for this paper suggests that unions should consider debunking this myth by exposing the enviable profits that media companies have secured and advocating that these profits be redistributed among interns and other journalism workers. Ultimately, unions must continue to fight for higher wages and resist exploitative internships, just as they resisted the use of cheap apprentice labour and the lack of editorial worker job security in the $19^{\text {th }}$ century and early $20^{\text {th }}$ century.

In light of broader discussions about a declining unionization rate under post-Fordist capitalism, the "embattled state of the union" (de Peuter 2014b, 41), and labour movement renewal (Foley and Baker 2009; Kumar and Schenk 2006), the relationship between collective representation and entry-level journalism intern pay rates in Canada illuminates the vital role of mediation that unions continue to play. The relatively high-paid journalism internships under union jurisdiction seem to bolster Simon Head's $(2003,172)$ claim that unions can still be "the worker's best defence." They are also evidence that well-paid internships are both possible and desirable. Unionized newspapers that pay interns entry-level rates could serve as a model for organizing unpaid and low-paid magazine interns and other precarious workers whose labour is devalued, both beyond the media industries and outside of Canada. 
Table 1: Journalism Internship Pay Rates and Collective Representation in Canada

\begin{tabular}{|c|c|c|c|c|c|}
\hline $\begin{array}{l}\text { Magazine }(\mathrm{m}) / \\
\text { Newspaper }(\mathrm{n})\end{array}$ & Owner & $\begin{array}{l}\text { Revenues }^{15} / \\
\text { Earnings }^{16} / \\
\text { Profit } \\
\text { Margin }^{17}\end{array}$ & Union & Interns $^{18}$ & Pay Rate (\$) \\
\hline Flare $(\mathrm{m})$ & $\begin{array}{l}\text { Rogers } \\
\text { Media }\end{array}$ & $\begin{array}{l}1,700 / 160 / \\
9.4 \%\end{array}$ & No & $\begin{array}{l}6 \\
\text { (18 per year) }\end{array}$ & Unpaid \\
\hline Chatelaine (m) & $\begin{array}{l}\text { Rogers } \\
\text { Media }\end{array}$ & $\begin{array}{l}1,700 / 160 / \\
9.4 \%\end{array}$ & No & N/A & $\begin{array}{l}400 \\
\text { (per month) }\end{array}$ \\
\hline Toronto Life (m) & $\begin{array}{l}\text { St. Joseph } \\
\text { Communications }\end{array}$ & $\begin{array}{l}32.1 / \mathrm{NA} / \\
\mathrm{NA}\end{array}$ & No & 5 & Unpaid \\
\hline $\begin{array}{l}\text { ELLE } \\
\text { Canada (m) }\end{array}$ & TC Media & $\begin{array}{l}712 / 40 / \\
5.6 \% \\
\end{array}$ & No & $\mathrm{N} / \mathrm{A}$ & $\begin{array}{l}750 \\
\text { (4 months) }\end{array}$ \\
\hline Toronto Sun $(\mathrm{n})$ & Quebecor Media & $\begin{array}{l}784.2 / 97.7 / \\
12.5 \%\end{array}$ & $\begin{array}{l}\text { Unifor } \\
\text { Local } \\
87-\mathrm{M}\end{array}$ & 4 & Unpaid \\
\hline Ottawa Sun (n) & Quebecor Media & $\begin{array}{l}784.2 / 97.7 / \\
12.5 \%\end{array}$ & $\begin{array}{l}\text { Unifor } \\
\text { Local } \\
87-M\end{array}$ & 3 & Unpaid \\
\hline $\begin{array}{l}\text { London Free } \\
\text { Press (n) }\end{array}$ & Quebecor Media & $\begin{array}{l}784.2 / 97.7 / \\
12.5 \%\end{array}$ & $\begin{array}{l}\text { Unifor } \\
\text { Local } \\
87-\mathrm{M}\end{array}$ & $\begin{array}{l}1 \\
\text { (4 per year) }\end{array}$ & Unpaid \\
\hline Maclean's (m) & $\begin{array}{l}\text { Rogers } \\
\text { Media }\end{array}$ & $\begin{array}{l}1,700 / 160 / \\
9.4 \%\end{array}$ & $\begin{array}{l}\text { Unifor } \\
\text { Local } \\
87-\mathrm{M}\end{array}$ & 2 & $\begin{array}{l}22,500 \text { (per year) } \\
1,750 \text { (per month) }\end{array}$ \\
\hline $\begin{array}{l}\text { Canadian } \\
\text { Business }(\mathrm{m})\end{array}$ & $\begin{array}{l}\text { Rogers } \\
\text { Media }\end{array}$ & $\begin{array}{l}1,700 / 160 / \\
9.4 \%\end{array}$ & No & 2 & $\begin{array}{l}24,000 \\
\text { (1 year) }\end{array}$ \\
\hline $\begin{array}{l}\text { Calgary } \\
\text { Herald (n) }\end{array}$ & Postmedia & $\begin{array}{l}\text { 751.6/130.4/ } \\
17.3 \%\end{array}$ & No & $3-4$ & 20 (hourly) \\
\hline $\begin{array}{l}\text { Victoria Times- } \\
\text { Colonist }(\mathrm{n})\end{array}$ & Glacier Media & $\begin{array}{l}295.6 / 32.7 / \\
11.1 \%\end{array}$ & $\begin{array}{l}\text { CWA- } \\
\text { Canada } \\
\text { Local } \\
30223\end{array}$ & 4 per year & $\begin{array}{l}554 \\
\text { (weekly) }\end{array}$ \\
\hline Toronto Star (n) & Torstar & $\begin{array}{l}984 / 130.7 / \\
13.3 \%\end{array}$ & $\begin{array}{l}\text { Unifor } \\
\text { Local } \\
87-\mathrm{M} \\
\end{array}$ & $\begin{array}{l}30-32 \\
\text { per year }\end{array}$ & $\begin{array}{l}954 \\
\text { (weekly) } \\
17 \text { (hourly) } \\
\end{array}$ \\
\hline $\begin{array}{l}\text { Winnipeg Free } \\
\text { Press (n) }\end{array}$ & $\begin{array}{l}\text { FP Canadian } \\
\text { Newspapers }\end{array}$ & $\begin{array}{l}106.3 / 20 / \\
18.8 \%\end{array}$ & $\begin{array}{l}\text { Unifor } \\
\text { Local } \\
191\end{array}$ & $\begin{array}{l}\text { N/A summer } \\
2-4 \text { school } \\
\text { year }\end{array}$ & $\begin{array}{l}65 \% \text { of } \\
\text { start rate } \\
50 \text { (weekly) }\end{array}$ \\
\hline $\begin{array}{l}\text { Globe and Mail } \\
(\mathrm{n})\end{array}$ & Woodbridge & $\begin{array}{l}350.4 / \mathrm{NA} / \\
\mathrm{NA}\end{array}$ & $\begin{array}{l}\text { Unifor } \\
\text { Local } \\
87-M\end{array}$ & $\begin{array}{l}18-20 \text { sum- } \\
\text { mer } \\
10 \text { per year } \\
\text { work study }\end{array}$ & $\begin{array}{l}\text { Entry level } \\
125 \\
\text { (weekly) }\end{array}$ \\
\hline $\begin{array}{l}\text { Waterloo } \\
\text { Region } \\
\text { Record }(\mathrm{n})\end{array}$ & Torstar & $\begin{array}{l}984 / 130.7 / \\
13.3 \%\end{array}$ & $\begin{array}{l}\text { Unifor } \\
\text { Local } \\
87-\mathrm{M}\end{array}$ & 4 & Entry level \\
\hline $\begin{array}{l}\text { Guelph } \\
\text { Mercury (n) }\end{array}$ & Torstar & $\begin{array}{l}984 / 130.7 / \\
13.3 \%\end{array}$ & $\begin{array}{l}\text { Unifor } \\
\text { Local } \\
87-\mathrm{M}\end{array}$ & 1-2 per year & Entry level \\
\hline $\begin{array}{l}\text { Ottawa } \\
\text { Citizen }(\mathrm{n})\end{array}$ & Postmedia & $\begin{array}{l}751.6 / 130.4 / \\
17.3 \%\end{array}$ & $\begin{array}{l}\text { CWA- } \\
\text { Canada } \\
\text { Local } \\
30205\end{array}$ & 6 & Entry level \\
\hline
\end{tabular}

\footnotetext{
${ }^{15}$ All dollar amounts are expressed in millions annually in Canadian dollars.

${ }^{16}$ Based on Earnings Before Interest, Taxes, Depreciation and Amortization (EBITDA).

${ }^{17}$ Calculated as revenues divided by earnings.

${ }^{18}$ Based on the number of interns at any one time in 2013 , unless otherwise noted.
} 


\begin{tabular}{|l|l|l|l|l|l|}
\hline $\begin{array}{l}\text { Vancouver } \\
\text { Province }(\mathrm{n})\end{array}$ & Postmedia & $\begin{array}{l}751.6 / 130.4 / \\
17.3 \%\end{array}$ & $\begin{array}{l}\text { Unifor } \\
\text { Local } \\
2000\end{array}$ & 4 & Entry level \\
\hline $\begin{array}{l}\text { Vancouver Sun } \\
(\mathrm{n})\end{array}$ & Postmedia & $\begin{array}{l}751.6 / 130.4 / \\
17.3 \%\end{array}$ & $\begin{array}{l}\text { Unifor } \\
\text { Local } \\
2000\end{array}$ & 3 & Entry level \\
\hline
\end{tabular}

\section{References}

Bakker, Piet. 2014. Mr. Gates Returns. Journalism Studies 15 (5): 596-606.

Baluja, Tamara. 2013. Chatelaine Seeking Web, Copy Editing and Editorial Interns. J-Source, December 3. Accessed June 26, 2015. http://j-source.ca/article/chatelaine-seeking-web-copy-editingand-editorial-interns.

Baluja, Tamara. 2014. Canadian Business Hiring One-Year Intern. J-Source, January 9. Accessed March 3, 2015.

http://j-source.ca/article/canadian-business-hiring-one-year-intern.

Bekken, Jon. 1995. Newsboys: The Exploitation of 'Little Merchants' by the Newspaper Industry. In Newsworkers: Toward a History of the Rank and File, edited by Hanno Hardt and Bonnie Brennen, 190-225. Minneapolis: University of Minnesota Press.

Bekken, Jon. 2009. Newsboy Strikes. In Encyclopedia of Strikes in American History, edited by Aaron Brenner, Benjamin Day and Immanuel Ness, 609-619. Armonk: M.E. Sharpe.

Bernstein, Irving. 2010. Unrest in Odd Places. In The Turbulent Years: A History of the American Worker, 1933-1941, 126-171. Boston: Houghton Mifflin. Reprint, Chicago: Haymarket Books. First published 1969.

Brophy, Enda and Greig de Peuter. 2007. Immaterial Labor, Precarity, and Recomposition. In Knowledge Workers in the Information Society, edited by Catherine McKercher and Vincent Mosco, 177-191. Lanham: Lexington Books.

Canadian Business. 2014. The Canadian Business Internship. Accessed March 22, 2015. http://www.canadianbusiness.com/blogs-and-comment/internship/.

Canadian Press. 2009. Torstar's Mercury, Spectator, Record Announce Layoffs. Guelph Mercury, February 23. Accessed March 11, 2015. https://web.archive.org/web/20090413210401/http://news.guelphmercury.com/News/BreakingNews larticle/444110.

CBC News. 2012. Postmedia Cutting Jobs, Sunday Editions. CBC News, May 28. Accessed March 6 , 2015. http://www.cbc.ca/news/business/postmedia-cutting-jobs-sunday-editions-1.1153950.

CEP (Communications, Energy and Paperworkers Union of Canada). 2000. PrintCEPles: Newsletter of CEP Local 191: Media Union of Manitoba and Northwest Ontario, September, 1 (3). Accessed March 23, 2015.

http://web.archive.org/web/20030622061850/http://www.cep191.ca/newsletters/2000_September.p df.

CEP. 2001. Maclean's Magazine Collective Agreement: January 1, 2001-December 31, 2003. Accessed March 18, 2015. https://web.archive.org/web/20050515104240/http://song.on.ca/macleans0103.pdf.

CEP. 2002a. The Globe and Mail Collective Agreement: July 1, 2002-June 30, 2005. Accessed March 23, 2015. http://web.archive.org/web/20050111122615/.

CEP. 2002b. The Guelph Mercury Collective Agreement: May 24, 2002-May 23, 2005. Accessed March 18, 2015. https://web.archive.org/web/20050515105704/http://song.on.ca/guelph0205.pdf.

CEP. 2003a. The Kitchener-Waterloo Region Record Collective Agreement: January 1, 1999December 31, 2003. Accessed March 18, 2015. https://web.archive.org/web/20030811135607/http://www.song.on.ca/PDF/kw_edit_99.pdf.

CEP. 2003b. Mercury Newsroom Gets Deal: Chain-Wide Support Gives Boost. SONG Sheet, June. Accessed March 18, 2015. https://web.archive.org/web/20040309115348/http://www.song.on.ca/songsheet june03.html.

CEP. 2007a. The London Free Press Collective Agreement: January 1, 2007-December 31, 2009. Accessed March 22, 2015.

http://www.unifor87m.org/sites/default/files/bargaining\%20Contract/LFPFinalAgreementPrinting.pdf.

CEP. 2007b. Maclean's Magazine Collective Agreement: January 1, 2007-December 31, 2009. Accessed March 18, 2015. 
https://web.archive.org/web/20111207234630/http://song.on.ca/files/MacleansCA-Jan12007Dec312009 000.pdf.

CEP. 2007c. The Ottawa Sun Collective Agreement: January 1, 2007-December 31, 2010. Accessed March 20, 2015.

http://www.unifor87m.org/sites/default/files/bargaining\%20Contract/OttawaSunJan12007Dec312010.pdf.

CEP. 2007d. Pacific Newspaper Group Collective Agreement. Accessed March 12, 2015. http://mediaunion.ca/wordpress/wp-content/uploads/2014/06/PNG-Part-A-Granville-Square.pdf.

CEP. 2008a. The Toronto Sun Collective Agreement: January 1, 2008-December 31, 2010. Accessed March 20, 2015. http://www.unifor87m.org/sites/default/files/bargaining\%20Contract/SunEdit20082010CARev.pdf.

CEP. 2008b. The Winnipeg Free Press Inside Workers Collective Agreement: October 1, 2008-June 30, 2013. Accessed March 23, 2015.

http://web.archive.org/web/20110912030659/http://www.cep191.ca/files/CA\%20\%20FP\%20Inside\%20Workers\%2008-13.pdf.

CEP. 2009. The Globe and Mail Editorial, Advertising, Circulation \& Maintenance Collective Agreement: July 1, 2009-June 30, 2014. Accessed March 12, 2015. http://www.unifor87m.org/sites/default/files/bargaining\%20Contract/652201 CEP GlobeAndMail 02.pdf.

CEP. 2011a. The Guelph Mercury Collective Agreement: May 24, 2011 to May 23, 2014. Accessed March 12, 2015. http://www.unifor87m.org/sites/default/files/bargaining\%20Contract/Guelph\%20MercuryCOLLECTIVE\%20AGREEMENT\%202011-2014\%20FINAL\%5B1\%5D.pdf.

CEP 2011b. Maclean's Magazine Editorial Collective Agreement: January 1, 2010-December 31, 2013. Accessed March 12, 2015.

http://www.unifor87m.org/sites/default/files/bargaining\%20Contract/Macleans\%20Editorial\%202010 -2013\%20Print\%20Ready.pdf.

CEP. 2011c. The Ottawa Sun Collective Agreement: January 1, 2011-December 31, 2013. Accessed March 12, 2015

http://www.unifor87m.org/sites/default/files/bargaining\%20Contract/Ottawa\%20Sun\%20CBA\%20Ja n\%201\%202011-\%20Dec\%2031\%202013 doc.pdf.

CEP. 2011d. The Toronto Sun Editorial and PrePress Collective Agreement: January 1, 2011December 31, 2013. Accessed March 12, 2015. http://www.unifor87m.org/sites/default/files/bargaining\%20Contract/Sun\%20Agreement\%20\%20Jan\%201-11\%20-\%20Dec\%2031\%20-\%2013.pdf.

CEP. 2011e. The Waterloo Region Record Editorial Collective Agreement: January 1, 2011-December 31, 2014. Accessed March 12, 2015.

http://www.unifor87m.org/sites/default/files/bargaining\%20Contract/WRREdit\%20CA\%20Final\%20Dec\%202012.pdf.

CEP. 2013a. Toronto Star Edition: News from the Star and Our Industry. SONG Sheet, May 21. Accessed March 4, 2015.

https://web.archive.org/web/20131021055333/http://www.song.on.ca/files/SONG\%20Sheet\%20Ma y\%2021\%281\%29.pdf.

CEP. 2013b. The London Free Press Editorial Collective Agreement: January 1, 2013-December 31, 2016. Accessed March 22, 2015. http://www.unifor87m.org/sites/default/files/LFP-EDITORIALAgreement-2013-READY\%20FOR\%20PRINT.pdf.

CEP. 2013c. The Toronto Star Newspapers Ltd. Collective Agreement: January 1, 2013-December 31, 2016. Accessed March 20, 2015. http://www.unifor87m.org/sites/default/files/Toronto\%20StarCollective\%20Agreement-January\%201\%2C\%202013\%20\%20December\%2031\%2C\%202016 0.pdf.

CEP. 2013d. The Winnipeg Free Press Inside Workers Collective Agreement: July 1, 2013-June 30, 2018. Accessed March 20, 2015. http://cep191.ca/wp-content/uploads/2012/10/WFP-CEP-July-12013-to-June-30-2018-Collective-Agreements.zip.

CMCRP (Canadian Media Concentration Research Project). 2013. Newspapers and Magazines. Accessed March 1, 2015. http://www.cmcrp.org/wp-content/uploads/2014/11/Pres-and-Mags-Eng2013.xlsx.

CMCRP. 2014. The Growth of Network Media Economy in Canada, 1984-2013. Accessed March 9, 2015. http://www.cmcrp.org/2014/11/20/the-growth-of-the-network-media-economy-in-canada1984-2013/. 
CMG (Canadian Media Guild). 2013. Preliminary Numbers 2013. Accessed October 25, 2014. http://www.cmg.ca/en/wp-content/uploads/2013/11/Preliminary-numbers-Print-Media-Job-cutsbetween-2008-2013-CMG.pdf.

Cohen, Nicole S. 2011. Negotiating Writers' Rights: Freelance Cultural Labour and the Challenge of Organizing. Just Labour: A Canadian Journal of Work and Society 17-18: 119-138.

Cohen, Nicole S. 2012. Cultural Work as a Site of Struggle: Freelancers and Exploitation. tripleC: Cognition, Communication, Cooperation 10 (2): 141-155. Accessed August 17, 2015. http://www.triple-c.at/index.php/tripleC/article/view/384.

Cohen, Nicole and Greig de Peuter. 2013. The Politics of Precarity: Can the Urban Worker Strategy Address Precarious Employment for All? Briarpatch, November 1. Accessed March 22, 2015. http://briarpatchmagazine.com/articles/view/urban-worker-strategy-andrew-cash.

CWA (Communications Workers of America) Canada. 2015. About Us. Accessed March 20, 2015. http://www.cwa-scacanada.ca/EN/menu/about us.shtml.

Davis, Charles. 2013. The Exploited Laborers of the Liberal Media. VICE, December 2. Accessed March 6, 2015. http://www.vice.com/read/the-exploited-laborers-of-the-liberal-media.

de Peuter, Greig. 2014a. Beyond the Model Worker: Surveying a Creative Precariat. Culture Unbound: Journal of Current Cultural Research 6: 263-284.

de Peuter, Greig. 2014b. Confronting Precarity in the Warhol Economy. Journal of Cultural Economy 7 (1): 31-47.

de Peuter, Greig, Nicole Cohen and Enda Brophy. 2012. Interns Unite! (You Have Nothing to LoseLiterally). Briarpatch, November 9. Accessed March 22, 2015. http://briarpatchmagazine.com/articles/view/interns-unite-you-have-nothing-to-lose-literally.

Denning, Michael. 2010. The Cultural Front: The Laboring of American Culture in the Twentieth Century. New York: Verso.

Deuze, Mark. 2007. Media Work. Malden: Polity Press.

Deuze, Mark and Timothy Marjoribanks. 2009. Newswork. Journalism 10 (5): 555-561.

DJNF (Dow Jones News Fund). 2015. History of the Fund. Accessed June 25, 2015. https://www.newsfund.org/PageText/AD HomePages.aspx?Page ID=AD HistoryOfFund.

Dobby, Christine and Canadian Press. 2013. Sun Media to Cut 360 jobs and Close 11 of its Newspapers, Including Three Free Urban Dailies. Financial Post, July 16. Accessed March 6, 2015. http://business.financialpost.com/2013/07/16/sun-media-job-cuts-closing/? Isa=1110-bc46.

Doorey, David. 2013. Doorey's Law of Work Blog: A Discussion of Issues and Debates for Students and Others. Accessed March 22, 2015. http://lawofwork.ca/.

Dorsey, James E. 1977. Industrial Relations Officers of the British Columbia Department of Labour. The Advocate 35: 381-404.

Edge, Marc. 2014. Greatly Exaggerated: The Myth of the Death of Newspapers. Vancouver: New Star Books.

ELLE Canada. 2011. ELLE Canada Editorial Internships. Accessed March 22, 2015. http://www.ellecanada.com/elle-canada-print-editorial-internships/a/47166\#.U3Lia6xgKnw.

Employment Standards Act, RSBC 1990, c 113.

Employment Standards Act, SO 2000, c 41.

Employment Standards Code, CCSM 1998, c E110.

Employment Standards Code, RSA 2000, c E-9.

Flare. 2014. Job and Internship Opportunities. Accessed March 4, 2015. http://www.flare.com/about/job-and-internship-opportunities/.

Fletcher, Jr., Bill and Fernando Gapasin. 2008. Solidarity Divided: The Crisis in Organized Labor and a New Path Toward Social Justice. Berkeley: University of California Press.

Foley, Janice R. and Patricia L. Baker, eds. 2009. Unions, Equity, and the Path to Renewal. Vancouver: UBC Press.

FP Newspapers. 2013. 2013 Annual Report: FP Newspapers Inc. Accessed March 2, 2015. http://www.fpnewspapers.com/investor-centre/annual-reports/annualrpt2013.pdf.

Fudge, Judy and Eric Tucker. 2001. Recognition and Responsibility: The Achievement of Industrial Pluralism, 1943-1948. In Labour Before the Law: The Regulation of Workers' Collective Action in Canada, 1900-1948, 263-301. Toronto: Oxford University Press Canada.

Galarneau, Diane, René Morissette and Jeannine Usalcas. 2013. What Has Changed for Young People in Canada? Catalogue no. 75-006-X. Ottawa: Statistics Canada. Accessed March 22, 2015. http://www.statcan.gc.ca/pub/75-006-x/2013001/article/11847-eng.pdf. 
Galarneau, Diane and Thao Sohn. 2013. Long-Term Trends in Unionization. Catalogue no. 75-006-X. Ottawa: Statistics Canada. Accessed March 16, 2015. http://www.statcan.gc.ca/pub/75-006x/2013001/article/11878-eng.pdf.

Gall, Gregor. 1997. The Changing Relations of Production: Union Derecognition in the UK Magazine Industry. Industrial Relations Journal 29 (2): 151-161.

Gaulin, Jeff. 2015. Multimedia Journalists - Summer Intern: Toronto Sun. Accessed June 25, 2015. https://web.archive.org/web/20150411073435/http://jeffgaulin.com/jobs/JobDetails.asp?id=19122.

Gill, Rosalind and Andy Pratt. 2008. In the Social Factory?: Immaterial Labour, Precariousness and Cultural Work. Theory, Culture \& Society 25 (7-8): 1-30.

Glacier Media. 2013. 2013 Glacier Annual Report. Accessed March 3, 2015. http://www.glaciermedia.ca/sites/gmg.tidaldevel.com/files/news/2013\%20Glacier\%20Annual\%20Re port.pdf.

Gollmitzer, Mirjam. 2014. Precariously Employed Watchdogs? Perceptions of Working Conditions among Freelancers and Interns. Journalism Practice 8 (6): 826-841.

Gould, Mark. 1981. The Devaluation of Labor-Power. Berkeley Journal of Sociology 26: 139-155.

Haddrall, Lynn. 2011. Four New Interns Will Be Combing Our Region for News. The Record, May 21. Accessed March 12, 2015. http://www.therecord.com/opinion-story/2580297-four-new-interns-willbe-combing-our-region-for-news/.

Haddrall, Lynn. 2012. Interns Bring Fresh Perspective to Local Coverage. The Record, May 26. Accessed March 12, 2015. http://www.therecord.com/opinion-story/2603243-interns-bring-freshperspective-to-local-coverage/.

Haddrall, Lynn. 2013. Record's Summer Students Will Be Flying High. The Record, May 18. Accessed March 12, 2015. http://www.therecord.com/opinion-story/3243227-record-s-summer-students-willbe-flying-high/.

Hardt, Michael and Antonio Negri. 2009. Commonwealth. Cambridge: Harvard University Press.

Head, Simon. 2003. The New Ruthless Economy: Work \& Power in the Digital Age. New York: Oxford University Press.

Hesmondhalgh, David. 2010. User-Generated Content, Free Labour and the Cultural Industries. Ephemera: Theory \& Politics in Organization 10 (3-4): 267-284.

Hesmondhalgh, David and Sarah Baker. 2011. Creative Labour: Media Work in Three Cultural Industries. New York: Routledge.

Houpt, Simon. 2014. Unpaid Internships at Magazines New Target of Ontario Labour Ministry. The Globe and Mail, March 27. Accessed March 22, 2015. http://www.theglobeandmail.com/arts/booksand-media/unpaid-internships-at-magazines-new-target-of-ontario-labourministry/article17694055/.

Huws, Ursula. 2014. Labor in the Global Digital Economy: The Cybertariat Comes of Age. New York: Monthly Review Press.

Internship, The: Generation i. 2014. The Economist, September 6. Accessed March 20, 2015. http://www.economist.com/news/international/21615612-temporary-unregulated-and-often-unpaidinternship-has-become-route.

Jay, Paul. 1995. All Work, No Pay. Ryerson Review of Journalism, Spring. Accessed February 25, 2015. http://www.journalism.ryerson.ca/m6047/.

Kumar, Pradeep and Christopher Schenk, eds. 2006. Paths to Union Renewal: Canadian Experiences. Peterborough: Broadview Press.

Ladurantaye, Steve. 2013. Toronto Star Union Says Paper is Looking to Outsource Radio Room Program. The Globe and Mail, March 4. Accessed March 4, 2015.

http://www.theglobeandmail.com/globe-investor/toronto-star-union-says-paper-is-looking-tooutsource-radio-room-program/article9284111/.

Laidlaw, Stuart. 2013. Star Bulletin: CEP Local 87-M, SONG. Accessed March 4, 2015. http://www.unifor87m.org/sites/default/files/bargaining\%20Contract/Radio\%20Room.pdf.

Langille, Andrew. 2014. Youth and Work: A Website about Youths, Workplace Law, Economics, Labour Markets, Education, \& Public Policy. Accessed March 22, 2015. http://www.youthandwork.ca/

LCO (Law Commission of Ontario). 2012. Vulnerable Workers and Precarious Work: Final Report. Accessed March 22, 2015. www.lco-cdo.org/en/vulnerable-workers-final-report.

Leab, Daniel J. 1970. A Union of Individuals: The Formation of the American Newspaper Guild, 19331936. New York: Columbia University Press. 
Learn, Joshua Rapp. 2013. Internship Opportunities Shrinking Across the Country. J-Source, May 1. Accessed March 20, 2015. http://j-source.ca/article/student-internship-opportunities-shrinkingacross-country.

Lee, Jenny. 2014. Newspapers Healthy Despite Kamloops Daily News Closure, Industry Spokesman Says. The Vancouver Sun, January 6. Accessed March 6, 2015. http://www.vancouversun.com/news/Newspapers+healthy+despite+Kamloops+Daily+News+closur e+industry+spokesman+says/9355158/story.html.

Logan, Edgar. 1965. Journalism: A Wide Open Field. The English Journal 54 (7): 623-625.

Lord, Titus. 1950. Unionism in Journalism. The Canadian Forum 30 (352): 25-29.

Lorey, Isabell. 2010. Becoming Common: Precarization as Political Constituting. e-flux 17. Accessed March 6, 2015. http://www.e-flux.com/journal/becoming-common-precarization-as-politicalconstituting/.

Maclean's. 2009. Internship Information. Accessed March 18, 2015. https://web.archive.org/web/20090415212412/.

Maclean's. 2014. Internship Information. Accessed March 20, 2015. http://www.macleans.ca/internship-information/

Madison, Eddie. 2014. Training Digital Age Journalists: Blurring the Distinction between Students and Professionals. Journalism \& Mass Communication Educator 69 (3): 314-324.

McKercher, Catherine. 2002. Newsworkers Unite: Labor, Convergence, and North American Newspapers. Lanham: Rowman \& Littlefield.

McKercher, Catherine. 2014. Precarious Times, Precarious Work: A Feminist Political Economy of Freelance Journalists in Canada and the United States. In Critique, Social Media and the Information Society, edited by Christian Fuchs and Marisol Sandoval, 219-230. New York: Routledge.

McKnight, Zoe. 2014. Unpaid Interns Dropped from Rogers-Owned Magazines. Toronto Star, April 3. Accessed March 3, 2015. http://www.thestar.com/news/gta/2014/04/03/unpaid interns dropped from rogersowned magazi nes.html.

Mercer, Katie. 2012. The Province is Hiring Summer Interns. The Province, October 25. Accessed March 12, 2015. http://blogs.theprovince.com/2012/10/25/the-province-is-hiring-summer-interns-2/.

Milkman, Ruth and Ed Ott, eds. 2014. New Labor in New York: Precarious Workers and the Future of the Labor Movement. Ithaca: ILR Press.

Mosco, Vincent and Catherine McKercher. 2008. The Laboring of Communication: Will Knowledge Workers of the World Unite? Lanham: Lexington Books.

Newspapers Canada. 2015. Circulation Report: Daily Newspapers 2014. Accessed June 22, 2015. http://www.newspaperscanada.ca/sites/default/files/2014_Circulation_ReportDaily Newspapers in Canada_FINAL 20150603 0.pdf.

OLRB (Ontario Labour Relations Board). 2013. About Us. Accessed June 25, 2015. http://www.olrb.gov.on.ca/english/aboutus.htm.

ONG (The Ottawa Newspaper Guild). 2013. Ottawa Citizen Contract, November 2013-November 2015. Accessed March 22, 2015. http://ottawanewsguild.ca/website/wpcontent/uploads/2009/07/Final-Nov-2013-Nov-2015-ONG-Ottawa-Citizen-Contract.doc.

Örnebring, Henrik. 2010. Technology and Journalism-as-Labour: Historical Perspectives. Journalism 11 (1): 57-74.

Paulussen, Steve. 2012. Technology and the Transformation of News Work: Are Labor Conditions in (Online) Journalism Changing? In The Handbook of Global Online Journalism, edited by Eugenia Siapera and Andreas Veglis, 192-208. Malden: Wiley-Blackwell.

Perlin, Ross. 2012. Intern Nation: How to Earn Nothing and Learn Little in the Brave New Economy. New York: Verso.

Postmedia. 2013. Postmedia Annual Report 2013. Accessed March 12, 2015. http://www.postmedia.com/wp-content/uploads/2013/11/2013-Annual-Report.pdf.

Quebecor Media. 2014. Quebecor Media 20-F 2013. Accessed March 2, 2015. http://www.quebecor.com/sites/default/files/QMI-20F-2013.pdf.

Ray, Regan. 2009. Layoffs at 3 TorStar Papers. J-Source, February 24. Accessed March 11, 2015. http://www.projetj.info/article/layoffs-3-torstar-papers.

Renzetti, Elizabeth. 1998. News Media Divided Over Unpaid Internships. The Globe and Mail, March 12, C1.

Rogers Communications. 2014. 2013 Annual Report. Accessed March 12, 2015. http://www.rogers.com/cms/investors/pdf/annual-reports/2013 Annual-Report.pdf. 
Salcetti, Marianne. 1995. The Emergence of the Reporter: Mechanization and the Devaluation of Editorial Workers. In Newsworkers: Toward a History of the Rank and File, edited by Hanno Hardt and Bonnie Brennen, 48-74. Minneapolis: University of Minnesota Press.

Scratch, Emma. 2004. Internships: The Good, the Bad, and the Ugly. Ryerson Review of Journalism, March. Accessed March 22, 2015. http://rrj.ca/internships-the-good-the-bad-and-the-ugly/

Skelton, Chad. 2013. No Fewer Journalists Today than 10 Years Ago: Statistics Canada. Vancouver Sun, August 19. Accessed March 22, 2015. http://blogs.vancouversun.com/2013/08/19/no-fewerjournalists-today-than-10-years-ago-statistics-canada/.

Skinner, David, James R. Compton and Mike Gasher. 2005. Mapping the Threads. In Converging Media, Diverging Politics: A Political Economy of News Media in the United States and Canada, edited by David Skinner, James R. Compton and Mike Gasher, 7-23. Lanham: Lexington Books.

Solomon, William S. 1995. The Site of Newsroom Labor: The Division of Editorial Practices. In Newsworkers: Toward a History of the Rank and File, edited by Hanno Hardt and Bonnie Brennen, 110134. Minneapolis: University of Minnesota Press.

Standing, Guy. 2011. The Precariat: The New Dangerous Class. London: Bloomsbury Academic.

Statistics Canada. 2013. Table 2: Low Income Cut-offs (1992 Base) Before Tax. Accessed March 22, 2015. http://www.statcan.gc.ca/pub/75f0002m/2013002/tbl/tb/02-eng.htm.

Stead, Sylvia. 2013. Public Editor: How Do Internships Work at The Globe? Find Out Here. The Globe and Mail, May 3. Accessed March 22, 2015. http://www.theglobeandmail.com/community/insidethe-globe/public-editor-how-do-internships-work-at-the-globe-find-out-here/article11704803/.

Stewart, Andrew and Rosemary Owens. 2013. Experience or Exploitation?: The Nature, Prevalence and Regulation of Unpaid Work Experience, Internships and Trial Periods in Australia. The University of Adelaide. Accessed March 22, 2015. http://www.fairwork.gov.au/Publications/Research/UWcomplete-report.pdf.

Stone, Felicity. 1999. Chasing the News beyond Ryerson. The Toronto Star, November 25, H8.

Tant, Lisa. 2010. An Honest Look at Internships. Flare, April 12. http://www.flare.com/fashion/anhonest-look-at-internships/.

Tatelman, Sara. 2015. Unpaid News: Are J-Schools Teaching Young Journalists to Work for Free? Briarpatch, February 23. Accessed March 6, 2015. http://briarpatchmagazine.com/articles/view/unpaid-news.

TC Transcontinental. 2013. 2013 TC Transcontinental Annual Report. Accessed March 12, 2015. http://tctranscontinental.com/documents/10180/37760/2013 Annual Report.pdf.

Thornton, Leslie-Jean. 2011. The Changing Role of Internships as Newsrooms Shrink and Evolve: Collaboration and Intern-as-Teacher. In Journalism Education, Training and Employment, edited by Bob Franklin and Donica Mensing, 130-142. New York: Routledge.

Toronto Life. 2014. Toronto Life Internship Program. Accessed June 25, 2015. https://web.archive.org/web/20140215084303/http://www.torontolife.com/internships/.

Toronto Life. 2015. Internships. Accessed June 25, 2015. http://www.torontolife.com/internships/.

Toronto Star. 2014. Star Internships. Accessed March 4, 2015. http://www.thestar.com/about/starinternships.html.

Toronto Star. 2015. Note to Readers: Star to End Paid Digital Subscriptions on April 1. Accessed June 22, 2015. http://www.thestar.com/news/gta/2015/03/07/note-to-readers-star-to-end-paid-digitalsubscriptions-on-april-1.html.

Torstar. 2013. Torstar 2013 Annual Report. Accessed March 2, 2015. http://www.torstar.com/images/file/2013/2013AnnualReport.pdf

Unifor87-M. 2013. Our History. Accessed March 20, 2015. http://www.unifor87m.org/our-history.

Ursell, Gillian. 2000. Television Production: Issues of Exploitation, Commodification and Subjectivity in UK Television Labour Markets. Media, Culture \& Society 22 (6): 805-825.

Ursell, Gillian. 2003. Creating Value and Valuing Creation in Contemporary UK Television: Or 'Dumbing Down' the Workforce. Journalism Studies 4 (1): 31-46.

Valpy, Michael. 1968. Black and White, and Yellow and Grey. The Globe and Mail, January 27, A6.

VVING (Victoria-Vancouver Island Newspaper Guild). 2011. Victoria Times-Colonist Memorandum of Agreement, January 2, 2011-January 1, 2015. Accessed March 1, 2015. http://vving.ca/wpcontent/uploads/2013/09/CWAContract_final.pdf.

Winnipeg Free Press. 2014. Internships at the Free Press. Accessed March 22, 2015. http://www.winnipegfreepress.com/internships.html.

Winseck, Dwayne. 2010. Financialization and the 'Crisis of the Media': The Rise and Fall of (Some) Media Conglomerates in Canada. Canadian Journal of Communication 35 (3): 365-393. 
Winseck, Dwayne. 2011. Part I: The Growth of the Network Media Economy. The Globe and Mail, August 23. Accessed March 23, 2015. http://www.theglobeandmail.com/technology/digitalculture/part-i-the-growth-of-the-network-media-economy-1984-2010/article626447/.

Wright, Erik Olin. 1997. Class Counts: Comparative Studies in Class Analysis. Cambridge: Cambridge University Press.

Zerker, Sally. 1975. George Brown and the Printers' Union. Journal of Canadian Studies 10: 42-48.

Zerker, Sally. 1982. The Rise and Fall of the Toronto Typographical Union, 1832-1972: A Case Study of Foreign Domination. Toronto: University of Toronto Press.

\section{About the Author}

Errol Salamon

Errol Salamon is a PhD candidate in communication studies at McGill University. He researches in the areas of critical political economy and communication history, especially as they intersect with creative work and labour, journalism, media policy, activism, alternative media, and digital technologies. He is co-editor and contributor to the forthcoming book Journalism in Crisis: Bridging Theory and Practice for Democratic Media Strategies in Canada (University of Toronto Press). 